\title{
Bioassay of Winter Wheat for Gibberellic Acid Sensitivity
}

\author{
Alexander D. Pavlista ${ }^{1 *}$, Dipak K. Santra ${ }^{1}$, David D. Baltensperger ${ }^{2}$ \\ ${ }^{1}$ Department of Agronomy and Horticulture, University of Nebraska, Panhandle Research \& Extension Center, Scottsbluff, USA; \\ ${ }^{2}$ Department of Soil and Crop Sciences, Texas A\&M University, College Station, USA. \\ Email: *apavlista@unl.edu
}

Received August 20 ${ }^{\text {th }}, 2013$; revised September 20 ${ }^{\text {th }}, 2013$; accepted October $8^{\text {th }}, 2013$

Copyright (c) 2013 Alexander D. Pavlista et al. This is an open access article distributed under the Creative Commons Attribution License, which permits unrestricted use, distribution, and reproduction in any medium, provided the original work is properly cited.

\begin{abstract}
Increasing winter wheat seedling growth would make it a better winter cover crop. Gibberellic acid $\left(\mathrm{GA}_{3}\right)$ seed treatment may accomplish this by stimulating stem growth. A bioassay, mimicking field conditions, could determine the relative sensitivity of conventional and semi-dwarf cultivars. In growth chambers set for $\operatorname{cool}\left(10^{\circ} \mathrm{C} / 4^{\circ} \mathrm{C}\right)$ and warm $\left(21^{\circ} \mathrm{C} / 4^{\circ} \mathrm{C}\right)$ conditions, wheat seeds were treated with 0 and 125 to $16,000 \mathrm{ppm} \mathrm{GA}_{3}$. The cultivars Goodstreak (tall or conventional) and Wesley (semi-dwarf) were compared as standards. Emergence and plant height were measured. "Goodstreak" showed a significant growth promotion at 500 ppm GA $\mathrm{A}_{3}$ when seeds were dipped and $2000 \mathrm{ppm}$ when $\mathrm{GA}_{3}$ was applied in-furrow under both temperature regimes. "Wesley" in general required the same or a higher dose of $\mathrm{GA}_{3}$. Separately, the seeds of nine other cultivars were treated with $\mathrm{GA}_{3}$ as the standards. Based on maximum height promotion, the most sensitive cultivars under cool conditions were Goodstreak, Harry, Millenium, and Wahoo; under warm conditions, the most sensitive cultivars were Alliance, Goodstreak, Jagalene, and Millenium. In general, the least $\mathrm{GA}_{3}$ sensitive cultivars were Arrowsmith, Scout66, and Wesley. "Buckskin" and "InfinityCL" were intermediate. The rye cultivar Rymin also was tested and showed less sensitivity to $\mathrm{GA}_{3}$ than "Goodstreak". When 6 benzyladenine (6BA) with $\mathrm{GA}_{3}$ was applied to "Goodstreak" and "Wesley" seed, emergence, plant height and weight, and tiller formation were reduced. Wheat cultivars will respond to $\mathrm{GA}_{3}$ and differ in the amount of $\mathrm{GA}_{3}$ needed. The results of this growth chamber study will guide subsequent field trials.
\end{abstract}

Keywords: Plant Growth Regulator; Gibberellin; Planting Aid; Cover Crop

\section{Introduction}

Introducing winter wheat into irrigated cropping systems is limited by an overlap between optimal planting date of winter crops such as wheat and rye with optimal harvest date for summer crops such as dry bean and potato in the High Plains [1]. Stimulating seedling growth of wheat under cooler conditions could allow later planting in the fall and possibly reduce wind erosion. Another aspect is that when soils are dry before planting winter wheat, it is recommended to plant seeds deeper, about $7.5 \mathrm{~cm}$, in the anticipation that the seedling roots will reach water. However, in this case, emergence takes longer and is less due to the greater distance for the coleoptile to reach the surface. In both cases, a stimulation of stem growth would improve wheat health.

A possible method of promoting stem growth of lateplanted and deep-planted winter wheat is to apply a growth promoter to seeds. This could enhance emergence

\footnotetext{
"Corresponding author.
}

and stem elongation. Recently [2], the promotion of seedling growth was accomplished with treating seeds with growth-promoting bacteria in a greenhouse. However, this may be accomplished directly by applying the natural product gibberellic acid $\left(\mathrm{GA}_{3}\right)$ to wheat seeds. The promotion of stem growth by gibberellins has been known since the 1930s when a rice disease was identified to be due to a pathogenic fungus Gibberella fujikuroi [3]. More than 130 gibberellins have been identified. $\mathrm{GA}_{3}$ is the key gibberellin, is highly active and is well known to stimulate stem elongation $[4,5]$. Greenhouse bioassays for stem elongation resulting from foliar-applied $\mathrm{GA}_{3}$ on legumes (Phaseolus vulgaris) have been reported [6,7]. Winter wheat stimulation by $\mathrm{GA}_{3}$ presents the problem that popular cultivars for irrigated wheat production are semidwarf, that is, they contain genes that may lower production of gibberellins or desensitize plants to endogenous $\mathrm{GA}_{3}$ and other gibberellins [8,9].

The genetics of plant height in wheat is known to be complex and is determined by more than 20 Rht ("re- 
duced height”) genes with different types of genetic mechanism, which are located across 17 of 21 chromosomes in wheat [10-13]. Depending on their reaction to exogenous $\mathrm{GA}_{3}$, the $R h t$ genes are classified into two groups: $\mathrm{GA}_{3}$-sensitive (synthesis mutants) and $\mathrm{GA}_{3}$-insensitive [11]. Dwarfism in wheat lines carrying $\mathrm{GA}_{3}$-sensitive genes is due to either the absence of or a modified spectrum of endogenous gibberellins. These genes are involved in $\mathrm{GA}_{3}$ biosynthesis and normal growth can be restored by exogenous $\mathrm{GA}_{3}$. The most important dwarfing gene of this category used agronomically in wheat is $R h t 8 c$ (formerly known as Rht8), which was first introduced into European wheat in the 1930s and now is widely used in many wheat cultivars adapted to warm climates $[14,15]$. The $\mathrm{GA}_{3}$-insensitive dwarfism in wheat lines is either due to reduced or lack of response to exogenous $\mathrm{GA}_{3}$. Major $\mathrm{GA}_{3}$-insensitive $R$ ht genes are at two loci on the chromosome 4BS and 4DS; each locus has multiple alleles that induce varying degrees of dwarfism. Four major $\mathrm{GA}_{3}$-insensitive genes are $R h t-B 1 b$ (formerly Rht1), Rht-D1b (formerly Rht2), Rht-B1c (formerly Rht3), and Rht-D1c (formerly Rht10) of which $R h t B 1 b$ and $R h t D 1 b$ are the two most widely $\mathrm{GA}_{3}$-insensitive dwarfing genes in modern wheat cultivars [16, 17]. Wheat cultivars carrying these semi-dwarf genes do not respond (increase in plant height) to endogenous $\mathrm{GA}_{3}$.

The objective of this study was to determine whether winter wheat cultivars, both regular and semi-dwarf types, would respond to seed-applied $\mathrm{GA}_{3}$ with increased stem elongation. This information would then be used in field trials to stimulate growth of late-season planted winter wheat.

\section{Materials and Methods}

\subsection{Growth Chamber Conditions}

Experiments were conducted in two growth chambers (Conviron model CMP 3023). One chamber was set for cool conditions, $10^{\circ} \mathrm{C}$ day and $4.4^{\circ} \mathrm{C}$ night, and the other for warm conditions, $21.1^{\circ} \mathrm{C}$ day and $4.4^{\circ} \mathrm{C}$ night (Figure 1). Plants were exposed to six hours (11 am to $5 \mathrm{pm}$ ) each day to either $10^{\circ} \mathrm{C}$ or $21.1^{\circ} \mathrm{C}$, and six hours $(11 \mathrm{pm}$ to $5 \mathrm{am})$ to $4.4^{\circ} \mathrm{C}$. The remaining hours were gradual transitions periods between day and night temperatures. Daylight was supplied by a bank of florescent light bulbs set at level 4 for a 12-hour photoperiod corresponding to day and night temperatures. Lamps were approximately $1.5 \mathrm{~m}$ above plants.

\subsection{Plant Material and Trial Conditions}

The winter wheat cultivars Goodstreak and Wesley were standards in all tests and in 2006, the cultivars Alliance, Arrowsmith, Buckskin, Harry, InfinityCL, Jagalene, Mil-

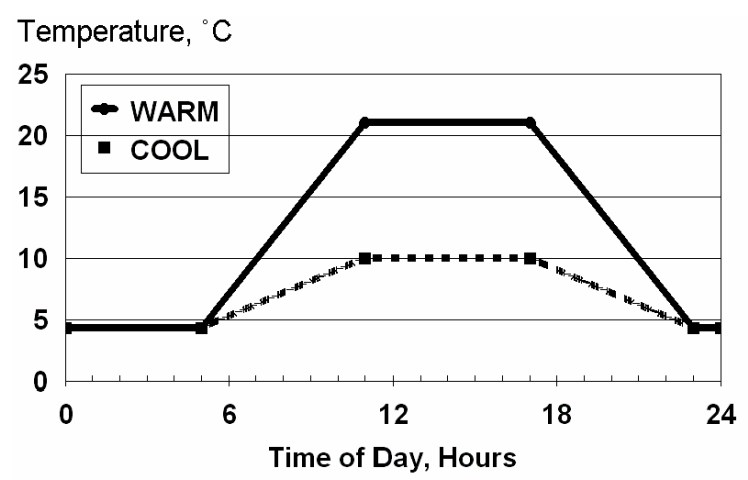

Figure 1. Temperature schedules for growth chamners.

lenium, Scout 66, and Wahoo were included (Table 1). All seed was certified and obtained locally. In 2007, the rye cultivar Rymin was tested with winter wheat cultivars Goodstreak and Wesley. Seeds were planted $1 \mathrm{~cm}$ deep in $36 \mathrm{~cm}$ by $51 \mathrm{~cm}$ flats lined with paper towels and filled with Fafard Superfine Germination Mix (American Clay Works, Denver, CO). Flats were soaked prior to planting and watered as needed. Each flat constituted a replication. Six seeds for each treatment and cultivar were planted $2.5 \mathrm{~cm}$ apart and $1 \mathrm{~cm}$ deep in rows that were $5 \mathrm{~cm}$ apart, 18 rows per flat. Three replications were placed in each of the two growth chamber.

\subsection{Experiments}

Gibberellic acid was applied as Release LC, a 4\% a.i. by weight formulation, i.e. $1 \mathrm{~g} \mathrm{GA}_{3} / 30 \mathrm{~mL}$, formulation (Valent BioScience Corp., Long Grove, IL). Release LC was diluted serially with water from 16,000 to $125 \mathrm{ppm}$ $\mathrm{GA}_{3}$. Experiments were conducted in 2005, 2006, 2007, and 2009. In 2009, 6-benzyladenine (6BA) as MaxCel, a $1.9 \%$ a.i. by weight formulation (Valent Bioscience) was added to $\mathrm{GA}_{3}$. In 2005, 36 seeds of "Goodstreak" and of "Wesley" were dipped for 2 minutes in $3 \mathrm{ml}$ of $\mathrm{GA}_{3}$ at 0 , $125,250,500,1000,2000,4000,8000$, or $16,000 \mathrm{ppm}$. Seeds were air-dried for three days before planting. In a second test in 2005, seeds were planted in flats and 0.125 $\mathrm{ml} / \mathrm{seed}$ of $\mathrm{GA}_{3}$ at 0 to $16,000 \mathrm{ppm}$ was applied in-furrow with a pipette. In 2006, seeds of nine winter wheat cultivars (listed above) plus "Goodstreak" and "Wesley" were dipped in 0, 250, 1000, 4000, and 16,000 ppm GA. Treatments were drained and seeds air-dried before planting. In 2007, the bioassay developed in 2005 using seed dipped in $\mathrm{GA}_{3}$ at $0,250,500$, and $1000 \mathrm{ppm}$ was used to test the sensitivity of rye cultivar Rymin in comparison with the wheat cultivars Goodstreak and Wesley under the warm growth chamber conditions. In 2009, the bioassay was conducted under warm conditions to test the influence of adding $6 \mathrm{BA}$ at $0,125,500$, and $2000 \mathrm{ppm}$ to $\mathrm{GA}_{3}$ at $0,500 \mathrm{ppm}$ for "Goodstreak", and $1000 \mathrm{ppm}$ for "Wesley". 
Table 1. Description of winter wheat cultivars.

\begin{tabular}{cccccc}
\hline Cultivar & Complimentary Grouping $^{1}$ & Height Description & Coleoptile Length & ${\text { Rht } \text { genes }^{2}}^{\text {References }}$ \\
\hline Alliance & Chisholm & Moderately short & Short & $R h t 1 B b(R h t 1)$ & {$[18]$} \\
Arrowsmith & - & Moderately tall & Moderately long & $R h t 1 B b(R h t 1)$ & {$[19]$} \\
Buckskin & Scout & Tall & Long & & {$[20]$} \\
Goodstreak & Colt & Tall & Long & & {$[21]$} \\
Harry & Brule & Moderately short & Short & $R h t 1 B b(R h t 1)$ & {$[22]$} \\
InfinityCL & - & Moderately tall & - & $R h t 1 B b(R h t 1)$ & {$[23]$} \\
Jagalene & Abilene & Moderately short & Moderately short & $R h t 1 B b(R h t 1)$ & Syngenta \\
Millenium & - & Moderately tall & Moderately short & $R h t 1 B b(R h t 1)$ & {$[24]$} \\
Scout66 & Scout & Tall & Long & & {$[25]$} \\
Wahoo & Arapahoe & Medium & Medium & $R h t 1 B b(R h t 1)$ & {$[26]$} \\
Wesley & Sumner & Short & Short & $R h t 1 B b(R h t 1) \& R h t 8 c$ & {$[27]$} \\
\hline
\end{tabular}

${ }^{1}$ Cultivars within each complimentary group share at least 50\% of the same parent lines. ${ }^{2}$ Source was [28] Guedira et al., 2010.

\subsection{Data and Statistical Analysis}

In 2005, emergence and plant heights were measured at 18 and 31 days after planting (DAP), and fresh weight was measured at 66 DAP. In 2006, only plant height was measured at 30 DAP under warm conditions and 40 DAP under cool conditions. In 2007, plant height was measured at 5 DAP under warm conditions. In 2009, measurements of emergence at 14 DAP, plant height at 17 and 28 DAP, and tiller number at 28 DAP were conducted under warm conditions. Data from each experiment were analyzed using SAS Proc ANOVA (version 9.1, SAS Institute, Cary, NC) and means were separated using least significant difference (SAS Institute) for each cultivar.

\section{Results}

\subsection{Bioassay Development}

In developing a bioassay for winter wheat sensitivity to $\mathrm{GA}_{3}$, cvs. Goodstreak with a regular growth habit and Wesley, a semi-dwarf, were treated and planted. These were placed in one of two growth chambers set to "warm" and "cool” conditions. Treatment was applied as a seed dip or as a furrow drip. Under warm conditions in 2005, the emergence of both Goodstreak and Wesley was unaffected by $\mathrm{GA}_{3}$ applied up to 2000 ppm applied as a seed dip, but above that, there was a significant decrease of emergence (Table 2). Under cool conditions, the emergence was not inhibited until the seed was treated with $8000 \mathrm{ppm}$. Furrow application of $\mathrm{GA}_{3}$ had no effect on emergence even at 16,000 ppm. Plant height at 18 DAP showed a significant increase when Goodstreak seed was treated with 500 ppm regardless of the chamber temperature regime (Table 2). With furrow treatment, height of Goodstreak was promoted as well but 2000 ppm was required to achieve a significant increase over the check. Wesley was less sensitive to $\mathrm{GA}_{3}$ than Goodstreak. For Wesley, plant height was increased by treating seed with 2000 ppm and placed in the warm chamber and 500 ppm when placed in the cool chamber (Table 2). Furrow application of $\mathrm{GA}_{3}$ required 4000 ppm in the warm chamber and 2000 ppm in the cool chamber to elicit a significant height increase.

\subsection{Cultivar Evaluation}

The seed of nine additional wheat cultivars were treated with $\mathrm{GA}_{3}$, planted and placed into the two growth chambers each with a different temperature regime. Under warm conditions, three cultivars, Infinity CL, Scout 66 and Wahoo, did not show a significant height increase with $\mathrm{GA}_{3}$ applied at $250 \mathrm{ppm}$ while the other eight of the 11 cultivars did (Table 3 ). Under cool conditions, three cultivars, Alliance, Buckskin and Jagalene, showed a decreased sensitivity to $\mathrm{GA}_{3}$ and three cultivars, Infinity CL, Scout 66 and Wahoo, showed an increased sensitivity compared to their performance under warm conditions (Table 3). The other five cultivars responded to the same exposure to $\mathrm{GA}_{3}$ under both temperature regimes. Note Goodstreak, a tall cultivar, reached a maximum response with 250 ppm $\mathrm{GA}_{3}$ while Wesley, a semi-dwarf cultivar, reached a maximum response at 1000 ppm (Table 3). Application of 4000 ppm $\mathrm{GA}_{3}$ increased plant height for all cultivars under both temperature regimes. When seeds were exposed to 16,000 ppm $\mathrm{GA}_{3}$, there was no emergence under cool conditions and $0 \%$ to $16 \%$ emergence under warm conditions (data not shown).

\subsection{Rye Comparison}

A short-term bioassay using seed dips and seeding under warm conditions was verified in 2007 and the rye cv. 
Table 2. Growth of winter wheat cvs. Goodstreak and Wesley grown in growth chambers set for $21.1^{\circ} \mathrm{C} / 4.4^{\circ} \mathrm{C}$ (warm chamber) or $10^{\circ} \mathrm{C} / 4.4^{\circ} \mathrm{C}$ (cool chamber) day/night temperature cycle after seed or furrow application of gibberellic acid (GA $\left.\mathbf{G}_{3}\right), 2005$.

\begin{tabular}{|c|c|c|c|c|c|c|c|c|}
\hline & \multicolumn{4}{|c|}{ "Goodstreak" } & \multicolumn{4}{|c|}{ “Wesley” } \\
\hline & \multicolumn{2}{|c|}{ Warm Chamber } & \multicolumn{2}{|c|}{ Cool Chamber } & \multicolumn{2}{|c|}{ Warm Chamber } & \multicolumn{2}{|c|}{ Cool Chamber } \\
\hline & Seed $^{1}$ & Furrow $^{1}$ & Seed & Furrow & Seed & Furrow & Seed & Furrow \\
\hline $\mathrm{GA}_{3} \mathrm{ppm}$ & \multicolumn{8}{|c|}{ Emergence at $18 \mathrm{DAP}^{2}, \%$} \\
\hline 0 & $100 \mathrm{~A}^{3}$ & 100 & $94 \mathrm{~A}$ & 100 & $100 \mathrm{~A}$ & 94 & $94 \mathrm{~A}$ & 100 \\
\hline 125 & $94 \mathrm{~A}$ & 94 & $100 \mathrm{~A}$ & 100 & $89 \mathrm{~A}$ & 72 & $89 \mathrm{~A}$ & 100 \\
\hline 250 & $94 \mathrm{~A}$ & 100 & $100 \mathrm{~A}$ & 94 & $94 \mathrm{~A}$ & 94 & $94 \mathrm{~A}$ & 89 \\
\hline 500 & $100 \mathrm{~A}$ & 100 & $100 \mathrm{~A}$ & 100 & $89 \mathrm{~A}$ & 100 & $94 \mathrm{~A}$ & 89 \\
\hline 1000 & $89 \mathrm{~A}$ & 100 & $100 \mathrm{~A}$ & 89 & $94 \mathrm{~A}$ & 89 & $89 \mathrm{~A}$ & 94 \\
\hline 2000 & $89 \mathrm{~A}$ & 100 & $100 \mathrm{~A}$ & 100 & $100 \mathrm{~A}$ & 100 & $94 \mathrm{~A}$ & 89 \\
\hline 4000 & $67 \mathrm{~B}$ & 94 & $100 \mathrm{~A}$ & 94 & $67 \mathrm{~B}$ & 100 & $78 \mathrm{~A}$ & 89 \\
\hline 8000 & $7 \mathrm{C}$ & 94 & $34 \mathrm{~B}$ & 100 & $12 \mathrm{C}$ & 94 & $44 \mathrm{~B}$ & 94 \\
\hline \multirow[t]{2}{*}{16000} & $2 \mathrm{C}$ & 94 & $2 \mathrm{C}$ & 100 & $2 \mathrm{C}$ & 83 & $2 \mathrm{C}$ & 94 \\
\hline & \multicolumn{8}{|c|}{ Plant height ${ }^{4}$ at 18 DAP, mm $^{5}$} \\
\hline 0 & $129 \mathrm{~B}$ & $123 \mathrm{D}$ & $54 \mathrm{~B}$ & $56 \mathrm{C}$ & $110 \mathrm{~B}$ & $115 \mathrm{~B}$ & $52 \mathrm{~B}$ & $53 \mathrm{C}$ \\
\hline 125 & $152 \mathrm{AB}$ & $131 \mathrm{CD}$ & $71 \mathrm{AB}$ & $53 \mathrm{C}$ & $128 \mathrm{AB}$ & $114 \mathrm{~B}$ & $66 \mathrm{AB}$ & $59 \mathrm{BC}$ \\
\hline 250 & $156 \mathrm{AB}$ & $130 \mathrm{CD}$ & $78 \mathrm{AB}$ & $52 \mathrm{C}$ & $134 \mathrm{AB}$ & 113 B & $71 \mathrm{AB}$ & $59 \mathrm{BC}$ \\
\hline 500 & $175 \mathrm{~A}$ & $127 \mathrm{CD}$ & $86 \mathrm{~A}$ & $52 \mathrm{C}$ & $133 \mathrm{AB}$ & $119 \mathrm{~B}$ & $79 \mathrm{~A}$ & $64 \mathrm{BC}$ \\
\hline 1000 & 195 A & $128 \mathrm{CD}$ & $90 \mathrm{~A}$ & $60 \mathrm{BC}$ & $133 \mathrm{AB}$ & $120 \mathrm{~B}$ & $78 \mathrm{~A}$ & $66 \mathrm{BC}$ \\
\hline 2000 & $188 \mathrm{~A}$ & $140 \mathrm{C}$ & $89 \mathrm{~A}$ & $67 \mathrm{~B}$ & 137 A & $124 \mathrm{~B}$ & $72 \mathrm{~A}$ & $71 \mathrm{AB}$ \\
\hline 4000 & $167 \mathrm{~A}$ & $169 \mathrm{~B}$ & $77 \mathrm{AB}$ & $77 \mathrm{~A}$ & $148 \mathrm{~A}$ & $137 \mathrm{~A}$ & $74 \mathrm{~A}$ & $72 \mathrm{AB}$ \\
\hline 8000 & $63 \mathrm{C}$ & $167 \mathrm{~B}$ & 52 B & $78 \mathrm{~A}$ & 107 B & 139 A & $63 \mathrm{AB}$ & $82 \mathrm{~A}$ \\
\hline 16000 & - & $197 \mathrm{~A}$ & - & $84 \mathrm{~A}$ & - & $139 \mathrm{~A}$ & - & $79 \mathrm{~A}$ \\
\hline
\end{tabular}

${ }^{1}$ Seeds were dipped in $\mathrm{GA}_{3}$ and then planted, or seeds were first planted and $\mathrm{GA}_{3}$ was applied with a pipette at $0.125 \mathrm{ml}$ per seed. ${ }^{2} \mathrm{DAP}=$ days after planting. ${ }^{3}$ Mean separation of $\mathrm{GA}_{3}$ rates for each column (cultivar, thermal period, and application method) using least significant difference at $P<0.05$. ${ }^{4} \mathrm{Plant}$ height was measured from potting soil to the highest leaf tip. ${ }^{5} 1$ inch $=254 \mathrm{~mm}$.

Table 3. Growth of eleven winter wheat cultivars grown in growth chambers set for either at $21.1^{\circ} \mathrm{C} / 4.4^{\circ} \mathrm{C}$ (warm chamber) or at $10^{\circ} \mathrm{C} / 4.4^{\circ} \mathrm{C}$ (cool chamber) day/night temperature cycle after seed application ${ }^{1}$ of gibberellic acid $\left(\mathrm{GA}_{3}\right), 2006$.

\begin{tabular}{|c|c|c|c|c|c|c|c|c|}
\hline & \multicolumn{4}{|c|}{ Warm Chamber at $30 \mathrm{DAP}^{2}$} & \multicolumn{4}{|c|}{ Cool Chamber at 40 DAP } \\
\hline & \multicolumn{8}{|c|}{$\mathrm{GA}_{3}, \mathrm{ppm}$} \\
\hline & 0 & 250 & 1000 & 4000 & 0 & 250 & 1000 & 4000 \\
\hline Cultivar & \multicolumn{8}{|c|}{ Plant height ${ }^{3}, \mathrm{~mm}^{4}$} \\
\hline Alliance & $258 \mathrm{~B}^{5}$ & $321 \mathrm{~A}$ & $319 \mathrm{~A}$ & $317 \mathrm{~A}$ & $163 \mathrm{~B}$ & $186 \mathrm{AB}$ & $216 \mathrm{~A}$ & $209 \mathrm{~A}$ \\
\hline Arrowsmith & $258 \mathrm{C}$ & 302 B & $318 \mathrm{AB}$ & $330 \mathrm{~A}$ & $178 \mathrm{C}$ & 203 B & $215 \mathrm{~B}$ & $231 \mathrm{~A}$ \\
\hline Buckskin & $268 \mathrm{C}$ & $321 \mathrm{~B}$ & $417 \mathrm{~A}$ & $461 \mathrm{~A}$ & $192 \mathrm{~B}$ & $212 \mathrm{~B}$ & $261 \mathrm{~A}$ & $273 \mathrm{~A}$ \\
\hline Goodstreak & 297 B & $375 \mathrm{~A}$ & $410 \mathrm{~A}$ & $428 \mathrm{~A}$ & $173 \mathrm{~B}$ & $235 \mathrm{~A}$ & $268 \mathrm{~A}$ & $293 \mathrm{~A}$ \\
\hline Harry & $241 \mathrm{C}$ & $277 \mathrm{~B}$ & $300 \mathrm{AB}$ & $328 \mathrm{~A}$ & $145 \mathrm{~B}$ & $175 \mathrm{~A}$ & $192 \mathrm{~A}$ & $187 \mathrm{~A}$ \\
\hline InfinityCL & $236 \mathrm{C}$ & $253 \mathrm{BC}$ & $272 \mathrm{AB}$ & $305 \mathrm{~A}$ & $143 \mathrm{C}$ & $175 \mathrm{~B}$ & $201 \mathrm{~A}$ & $200 \mathrm{~A}$ \\
\hline Jagalene & $214 \mathrm{~B}$ & $256 \mathrm{~A}$ & $250 \mathrm{~A}$ & 267 A & $147 \mathrm{~B}$ & $171 \mathrm{AB}$ & $185 \mathrm{~A}$ & $183 \mathrm{~A}$ \\
\hline Millenium & $221 \mathrm{~B}$ & $259 \mathrm{~A}$ & $255 \mathrm{~A}$ & $277 \mathrm{~A}$ & $161 \mathrm{~B}$ & $190 \mathrm{~A}$ & $196 \mathrm{~A}$ & $206 \mathrm{~A}$ \\
\hline Scout66 & 308 B & 324 B & $350 \mathrm{~B}$ & $440 \mathrm{~A}$ & $153 \mathrm{~B}$ & $161 \mathrm{~B}$ & $217 \mathrm{~A}$ & $217 \mathrm{~A}$ \\
\hline Wahoo & $251 \mathrm{~B}$ & $272 \mathrm{AB}$ & $272 \mathrm{AB}$ & $282 \mathrm{~A}$ & $156 \mathrm{~B}$ & $197 \mathrm{~A}$ & $196 \mathrm{~A}$ & $189 \mathrm{~A}$ \\
\hline Wesley & $227 \mathrm{C}$ & 274 B & $303 \mathrm{~A}$ & $306 \mathrm{~A}$ & $154 \mathrm{C}$ & 186 B & $194 \mathrm{AB}$ & $212 \mathrm{~A}$ \\
\hline
\end{tabular}

${ }^{1}$ Seeds were dipped in $\mathrm{GA}_{3}$ and then planted in flats. ${ }^{2} \mathrm{DAP}=$ days after plating. ${ }^{3}$ Plant height was measured from potting soil to the highest leaf tip. ${ }^{4} 1$ inch $=$ $254 \mathrm{~mm}$. ${ }^{5}$ Mean separation of $\mathrm{GA}_{3}$ rates for each cultivar (row) using least significant differences at $P<0.05$. 
Rymin was tested. Goodstreak showed a significant height increase at 5 and 13 DAP when treated with 500 ppm $\mathrm{GA}_{3}$ while Wesley did not show a response this early even with 1000 ppm (Table 4). This agreed with the test in 2005 when height was measured at 18 DAP, but in 2007, a response was observed for both wheat cultivars at $250 \mathrm{ppm}$ when measurements were taken 30 DAP (Table 3). The rye cv. Rymin did not show a height increase until seeds were exposed to 1000 ppm (Table 4).

\subsection{Addition of 6BA}

In 2009, this bioassay was used to determine whether 6BA could supplement $\mathrm{GA}_{3}$ growth promotion and in- crease tillering of wheat seedlings. Goodstreak seed was treated with 500 ppm $\mathrm{GA}_{3}$ with and without three concentrations of 6BA, 125, 500 and 2000 ppm. Wesley was likewise treated but 1000 ppm $\mathrm{GA}_{3}$ was used. Goodstreak when treated with 500 ppm $\mathrm{GA}_{3}$ alone showed a significant height promotion at 17 and 28 DAP (Table 5) as expected from the bioassay. But when adding 6BA at 500 ppm or 2000 ppm, height was decreased as well as tiller number and plant fresh weight (Table 5). Wesley height was not affected by 1000 ppm $\mathrm{GA}_{3}$ as in previous tests but the addition of 6BA at 2000 ppm decreased plant height, plant weight and tiller number (Table 5). 6BA at 2000 ppm also suppressed emergence of both cultivars.

Table 4. Plant height of rye cv. Rymin in comparison ti winter wheat cvs. Goodstreak and Wesley grown in a growth chamber set for $21.1^{\circ} \mathrm{C} / 4.4^{\circ} \mathrm{C}$ (warm chamber) day/night temperature cycle after seed application ${ }^{1}$ of gibberellic acid (GA $\mathrm{A}_{3}$ ), 2007.

\begin{tabular}{ccccccc}
\hline & \multicolumn{2}{c}{ Rye cv. Rymin } & \multicolumn{2}{c}{ Wheat cv. Goodstreak } & \multicolumn{2}{c}{ Wheat cv. Wesley } \\
\cline { 2 - 7 } & 5 DAP $^{2}$ & 13 DAP & 5 DAP & 13 DAP & 5 DAP & 13 DAP \\
\hline GA $_{3}$ Ppm & & \multicolumn{2}{c}{ Plant height, mm ${ }^{3,4}$} & $203 \mathrm{~B}$ & 98 & 166 \\
\hline 0 & $136 \mathrm{~B}^{5}$ & $173 \mathrm{~B}$ & $112 \mathrm{~B}$ & $210 \mathrm{~B}$ & 105 & 174 \\
125 & $153 \mathrm{AB}$ & $190 \mathrm{AB}$ & $115 \mathrm{~B}$ & $204 \mathrm{~B}$ & 103 & 159 \\
500 & $154 \mathrm{AB}$ & $199 \mathrm{AB}$ & $115 \mathrm{~B}$ & $232 \mathrm{~A}$ & 107 & 176 \\
1000 & $158 \mathrm{AB}$ & $198 \mathrm{AB}$ & $134 \mathrm{~A}$ & $235 \mathrm{~A}$ & 108 & 175 \\
\hline
\end{tabular}

${ }^{1}$ Seeds were dipped in $\mathrm{GA}_{3}$ and then planted. ${ }^{2} \mathrm{DAP}=$ days after planting. ${ }^{3} \mathrm{Plant}$ height was measured from potting soil to the highest leaf tip. ${ }^{4} 1 \mathrm{inch}=254$ mm.

${ }^{5}$ Mean separation of $\mathrm{GA}_{3}$ rates for each column using least significant difference at $P<0.05$.

Table 5. Growth of winter wheat cvs. Goodstreak and Wesley grown in a growth chamber set for $21.1^{\circ} \mathrm{C} / 4.4^{\circ} \mathrm{C}($ warm chamber) day/night temperature cycle after seed application ${ }^{1}$ of gibberellic acid $\left(\mathrm{GA}_{3}\right)$ with 6-benzyladenine (6BA), 2009.

\begin{tabular}{|c|c|c|c|c|c|c|}
\hline \multirow[b]{3}{*}{$\mathrm{GA}_{3}$} & \multirow[b]{3}{*}{$6 \mathrm{BA}$} & \multicolumn{5}{|c|}{ Wheat cv. Goodstreak } \\
\hline & & \multirow{2}{*}{$\begin{array}{c}\text { Emergence } \\
14 \mathrm{DAP}^{3}\end{array}$} & \multicolumn{2}{|c|}{ Plant height ${ }^{2}$} & \multirow{2}{*}{$\begin{array}{c}\text { Tiller/plant } \\
28 \text { DAP }\end{array}$} & \multirow{2}{*}{$\begin{array}{c}\text { Plant weight } \\
28 \text { DAP }\end{array}$} \\
\hline & & & 17 DAP & 28 DAP & & \\
\hline ppm & ppm & $\%$ & \multicolumn{2}{|c|}{$\mathrm{mm}^{4}$} & $\#$ & $\mathrm{~g}^{4} /$ plant \\
\hline 0 & 0 & $97 \mathrm{~A}^{5}$ & $103 \mathrm{~B}$ & $139 \mathrm{~B}$ & $3.0 \mathrm{~A}$ & $0.13 \mathrm{~A}$ \\
\hline 500 & 0 & $97 \mathrm{~A}$ & $132 \mathrm{~A}$ & $176 \mathrm{~A}$ & $3.0 \mathrm{~A}$ & $0.15 \mathrm{~A}$ \\
\hline 500 & 125 & $97 \mathrm{~A}$ & $125 \mathrm{~A}$ & $172 \mathrm{~A}$ & $3.0 \mathrm{~A}$ & $0.12 \mathrm{AB}$ \\
\hline 500 & 500 & $100 \mathrm{~A}$ & $120 \mathrm{AB}$ & 149 B & $2.6 \mathrm{~B}$ & $0.10 \mathrm{~B}$ \\
\hline \multirow[t]{2}{*}{500} & 2000 & $43 \mathrm{~B}$ & $66 \mathrm{C}$ & $77 \mathrm{C}$ & $2.1 \mathrm{C}$ & $0.04 \mathrm{C}$ \\
\hline & & \multicolumn{5}{|c|}{ Wheat cv. Wesley } \\
\hline 0 & 0 & $93 \mathrm{~A}$ & $89 \mathrm{~A}$ & $131 \mathrm{AB}$ & $3.4 \mathrm{~A}$ & $0.15 \mathrm{~A}$ \\
\hline 1000 & 0 & $87 \mathrm{~A}$ & $98 \mathrm{~A}$ & $149 \mathrm{~A}$ & $3.1 \mathrm{~A}$ & $0.15 \mathrm{~A}$ \\
\hline 1000 & 125 & $87 \mathrm{~A}$ & $98 \mathrm{~A}$ & $142 \mathrm{AB}$ & $3.3 \mathrm{~A}$ & $0.15 \mathrm{~A}$ \\
\hline 1000 & 500 & $90 \mathrm{~A}$ & $89 \mathrm{~A}$ & $113 \mathrm{~B}$ & $2.9 \mathrm{~A}$ & $0.09 \mathrm{~B}$ \\
\hline 1000 & 2000 & $17 \mathrm{~B}$ & $48 \mathrm{~B}$ & $76 \mathrm{C}$ & $1.9 \mathrm{~B}$ & $0.09 \mathrm{~B}$ \\
\hline
\end{tabular}

${ }^{1}$ Seeds were dipped in $\mathrm{GA}_{3}$ with or without $6 \mathrm{BA}$, and then planted. ${ }^{2}$ Plant height was measured from potting soil to the highest leaf tip. ${ }^{3} \mathrm{DAP}=$ days after planting. ${ }^{4} 1$ inch $=254 \mathrm{~mm} ; 1 \mathrm{oz}=28.35 \mathrm{~g} .{ }^{5}$ Mean separation of $\mathrm{GA}_{3}$ rates for each column for each cultivar using least significant difference at $P<0.05$. 


\section{Discussion}

\subsection{Wheat cv. Goodstreak and Wesley}

"Goodstreak" is a hard red winter wheat that is welladapted to western Nebraska [21]. It grows to a conventional height, tall, and has a long coleoptile (Table 1) adapted for low moisture conditions. "Wesley" is a hard red winter wheat, short with a short coleoptile (Table 1) and has a high yield potential in the north central Great Plains [27]. It is a semi-dwarf whose height tends to be about 15\% shorter than "Goodstreak" [21]. Semi-dwarf cultivars tend to emerge erratically due to their slow growth and short coleoptiles. For comparing conventional and semi-dwarf sensitivity to $\mathrm{GA}_{3}$, these two cultivars were deemed excellent representatives. Table 2 did not show a difference in emergence between "Goodstreak" and "Wesley" either between their untreated checks or their response to $\mathrm{GA}_{3}$ applied as a seed dip or in furrow up to 2000 ppm under warm conditions and up to 4000 ppm under cool conditions. $\mathrm{GA}_{3}$ applied to the seed at $4000 \mathrm{ppm}$ under warm conditions and at $8000 \mathrm{ppm}$ under cool conditions significantly lowered emergence and higher rates nearly eliminated it. Furrow application of $\mathrm{GA}_{3}$ had no effect on emergence.

\subsection{Wheat Bioassay Comparisons}

Allan et al. [29] began developing a bioassay for $\mathrm{GA}_{3}$ sensitivity for wheat by consecutively injecting $100 \mathrm{ppm}$ $\mathrm{GA}_{3}$ into vernalized seedlings transferred into a greenhouse. Dwarf and semi-dwarf cultivars were tested. The shortest cultivars were insensitive to $\mathrm{GA}_{3}$ injection. The three tallest cultivars did respond to $\mathrm{GA}_{3}$ but did not attain the height associated with conventional cultivars. Under both warm and cool conditions, $\mathrm{GA}_{3}$ seed- and furrow-treated "Wesley" attained the height of untreated “Goodstreak” (Table 2). Pinthus and Abraham [30] grew wheat plants of two cultivars with lines differing in heightreducing alleles in vermiculite drenched in 25 ppm $\mathrm{GA}_{3}$ and placed in growth chambers set at continuous $11^{\circ} \mathrm{C}$ or $25^{\circ} \mathrm{C}$. They reported that the tall cultivar, containing no height reducing alleles, responded to $\mathrm{GA}_{3}$ but as dwarfing increased in the lines, the response greatly diminished. At the higher temperature, height increased more rapidly than at cooler temperatures. Table 2 showed that for "Goodstreak" temperature did not affect $\mathrm{GA}_{3}$ sensitivity for the stimulation of plant height. For "Wesley" however, cool $\left(10^{\circ} \mathrm{C}\right)$ conditions increased the sensitivity to both seed- and furrow-applied $\mathrm{GA}_{3}$ stimulation of growth. Pereira et al. [31] soaked wheat seeds in $\mathrm{GA}_{3}$ for $4 \mathrm{~d}$. At $2^{\circ} \mathrm{C}$, maximum stimulation of coleoptile length was with 500 ppm $\mathrm{GA}_{3}$ for all isolines. At $18^{\circ} \mathrm{C}$, the response to $\mathrm{GA}_{3}$ was diminished in dwarfing isolines. They concluded that $\mathrm{GA}_{3}$ insensitivity was highly influenced by higher temperatures as was observed with "Wesley" (Table 2).
Comparing the two cultivars, "Goodstreak" was more sensitive to $\mathrm{GA}_{3}$ than "Wesley" under warm $\left(21^{\circ} \mathrm{C}\right)$ conditions. Table 2 suggested that to best highlight differences between these cultivars is to bioassay for $\mathrm{GA}_{3}$ response with seed treatment instead of furrow and possibly to grow plants under the warmer conditions. The higher exposure to $\mathrm{GA}_{3}$ for height stimulation from Wesley compared to Goodstreak is expected because Wesley carries $R h t-B 1 b$ and $R h t 8 c$, two $\mathrm{GA}_{3}$-insensitive genes whereas Goodstreak is not known to carry any such genes. The response of leaf length to applied $\mathrm{GA}_{3}$ in the $R h t-B 1 b$ and $R h t-D 1 b$ genotypes increased significantly with lowering of temperature [32]. We also found similar effect of lower temperature in Wesley.

\subsection{Cultivar Comparisons}

Table 3 showed no distinct pattern between cultivars, conventional or semi-dwarf, in sensitivity to $\mathrm{GA}_{3}$ applied to seed at either temperature. Some cultivars were less sensitive to $\mathrm{GA}_{3}$ under cooler conditions while some showed no difference. Except for three cultivars, Buckskin, Goodstreak, and Scout 66, eight of 11 cultivars in this study carry the same $\mathrm{GA}_{3}$-insensitive semi-dwarf gene Rth-B1b. Wesley carries this gene plus the $\mathrm{GA}_{3}-$ sensitive gene Rht8c. The lack of uniform pattern in $\mathrm{GA}_{3}$ response among these eight cultivars may be associated with additional factors. Both Rht-B1b and Rht8c act in semi-dominant fashion, where the genetic background plays an important role in the extent of $\mathrm{GA}_{3}$ response of these genes [11]. Except for the cultivars, Buckskin and Scout 66, other cultivars with known complementary group belong to different complementary groups indicating significant difference in their genetic background. Although dwarf phenotype is associated with $\mathrm{GA}_{3}$ function, another plant hormone, indole-acetic acid (IAA) also plays a role in cell elongation [33,34]. Differences in GA3 response at warm and cool temperatures among different cultivars may be related to a temperature effect on leaf elongation as mediated by the level of endogenous $\mathrm{GA}_{1}$. The leaf elongation response to endogenous and exogenous $\mathrm{GA}_{3}$ may be restricted by the upper limits set by the different Rht alleles [32]. Further study will be necessary to understand basis of such different response of these cultivars to $\mathrm{GA}_{3}$.

\subsection{Winter Rye}

Winter rye as wheat may be used as a cover crop [35] as well as used for livestock feed and pasture [36]. Like winter wheat, winter rye cultivars may have dwarfing characteristics related to either $\mathrm{GA}_{3}$ insensitivity and synthesis mutants [11]. "Rymin" registered in 1973 [37] is a popular rye grown throughout Nebraska. It grows to a tall or medium height [36,37]. Therefore, $\mathrm{GA}_{3}$ was ap- 
plied to seeds of "Rymin" rye and compared to "Goodstreak" and "Wesley" wheat under warm $\left(21^{\circ} \mathrm{C}\right)$ daytime conditions (Table 4). The sensitivity of "Rymin" to $\mathrm{GA}_{3}$ exposure was less than that of "Goodstreak" but greater than that of "Wesley". This may indicate that "Rymin" rye responded intermediately between "Goodstreak" and "Wesley" wheat.

\subsection{Cytokinin Addition}

It is well documented that cytokinins promote the growth of lateral buds $[4,38]$. For cereals, this would suggest that cytokinins could promote tiller formation. One commonly used cytokinin is 6BA. Since $\mathrm{GA}_{3}$ promoted stem growth of wheat, this might be enhanced by adding 6BA to promote tillering as well. Table 4 showed that adding 6BA to $\mathrm{GA}_{3}$ had no affect on enhancing emergence, seedling height, tiller number, or seedling weight compared to $\mathrm{GA}_{3}$ alone. 6BA at $2000 \mathrm{ppm}$ had an inhibitory effect on these growth parameters when added to $\mathrm{GA}_{3}$; at $500 \mathrm{ppm}, 6 \mathrm{BA}$ inhibited some of these parameters.

\section{Conclusion}

Treating seed of winter wheat cultivars with $\mathrm{GA}_{3}$ and planting in shallow flats placed under warm daytime temperature $\left(21^{\circ} \mathrm{C}\right)$ with cold nighttime $\left(4^{\circ} \mathrm{C}\right)$ temperatures is a good short turn-around ( 1 to $3 \mathrm{w}$ ) bioassay for both conventional and semi-dwarf cultivars. Winter rye can be tested in the same system. The next study will be to test $\mathrm{GA}_{3}$-treated winter wheat under field conditions and determine whether the growth of late-planted wheat could be stimulated to grow to that size of normally planted wheat.

\section{Acknowledgements}

We thank Les Kampbell and Eric Nielsen for their technical assistance, and the financial support by the Nebraska Wheat Board and Nebraska Crop Improvement Association.

\section{REFERENCES}

[1] USDA, "Usual Planting and Harvesting Dates for US Field Crops,” Agricultural Handbook \# 628, National Agricultural Statistics Services, Washington DC, 1997.

[2] W. A. Kasim, M. E. Osman, M. N. Omar, I. A. Abd ElDain, S. Bejai and J. Meijer, "Control of Drought Stress in Wheat Using Plant-Growth-Promoting Bacteria,” Journal of Plant Growth Regulations, Vol. 32, 2013, pp. 122130. http://dx.doi.org/10.1007/s00344-012-9283-7

[3] N. Takahashi, B. O. Phinney and J. MacMillan, "Gibberellins,” Springer-Verlag, NYC, New York, 1991. http://dx.doi.org/10.1007/978-1-4612-3002-1

[4] P. J. Davies, "Plant Hormones: Biosynthesis, Signal
Transduction, Action,” 3rd Edition, Springer-Verlag, NYC, New York, 2010.

[5] P. C. Marth, W. V. Audia and J. W. Mitchell, "Effects of Gibberellic Acid on Growth and Development of Plants of Various Genera and Species,” Botanical Gazette, Vol. 118, 1956, pp. 106-111.

http://dx.doi.org/10.1086/335932

[6] M. Knoche, N. K. Lownds and M. J. Bukovac, "Spray Application Factors and Plant Growth Regulator Performance: IV. Dose Response Relationships,” American Society for Horticultural Science, Vol. 125, 2000, pp. 195199.

[7] A. D. Pavlista, D. K. Santra, J. A. Schild and G. W. Hergert, "Gibberellic Acid Sensitivity among Common Bean Cultivars (Phaseolus vulgaris L.),” HortScience, Vol. 47, 2012, pp. 637-642.

[8] V. B. Busov, A. M. Brunner and S. H. Strauss, "Genes for Control of Plant Stature and Form,” New Phytologist, Vol. 177, 2008, pp. 589-607. http://dx.doi.org/10.1111/j.1469-8137.2007.02324.x

[9] J. Peng, D. E. Richards, N. M. Hartley, G. P. Murphy, K. M. Devos, J. E. Flintham, J. Beales, L. J. Fish, A. J. Worland, F. Pelica, D. Sudhakar, P. Christou, J. W. Snape, M. D. Gale and N. P. Harberd, “'Green Revolution’ Genes Encode Mutant Gibberellin Response Modulator,” Nature, Vol. 400, 1999, pp. 256-261. http://dx.doi.org/10.1038/22307

[10] M. D. Gale and S. Youssefian, "Dwarfing Genes in Wheat," In: G. E. Russell, Ed., Progress in Plant Breeding, Butterworth, London, 1985, pp. 1-35.

[11] A. Borner, J. Plaschke, V. Korzun and A. J. Worland, “The Relationships between the Dwarfing Genes of Wheat and Rye,” Euphytica, Vol. 89, 1996, pp. 69-75. http://dx.doi.org/10.1007/BF00015721

[12] M. H. Ellis, G. J. Rebetzke, F. Azana, R. A. Richards and W. Spielmeyer, "Molecular Mapping of Gibberellin-Responsive Dwarfing Genes in Bread Wheat," Theoretical and Applied Genetics, Vol. 111, 2005, pp. 423-430. http://dx.doi.org/10.1007/s00122-005-2008-6

[13] X. P. Li, S. Q. Lan and M. J. Li, "Dwarfing Genes in Wheat,” Chinese Agriculture Press, Beijing, 2010.

[14] V. Korzun, M. S. Roder, M. W. Ganal, A. J. Worland and C. N. Law, "Genetic Analysis of the Dwarfing Gene (Rht8) Part I. Molecular Mapping of Rht8 on the Short arm of Chromosome 2D of Bread Wheat (Triticum aestivum L.)," Theoretical and Applied Genetics, Vol. 96, 1998, pp. 1104-1109. http://dx.doi.org/10.1007/s001220050845

[15] A. J. Worland, V. Korzun, M. S. Roder, M. W. Ganal and C. N. Law, "Genetic Analysis of the Dwarfing Gene (Rht8) in Wheat. Part II. The Distribution and 77 Adaptive Significance of Allelic Variants at the Rht8 Locus of Wheat as Revealed by Microsatellite Screening,” Theoretical and Applied Genetics, Vol. 96, 1998, pp. 1110-1120. http://dx.doi.org/10.1007/s001220050846

[16] M. D. Gale and G. A. Marshall, "The Chromosomal Location of Gai1 and Rht1 Genes for Gibberellin Insensitivity and Semi-Dwarfism in a Derivative of Norin 10 Wheat," Heredity, Vol. 37, 1976, pp. 283-289. http://dx.doi.org/10.1038/hdy.1976.88 
[17] J. A. McVittie, M. D. Gale, G. A. Marshall and B. Westcott, "The Intrachromosomal Mapping of the Norin 10 and Thom Thumb Dwarfing Gene,” Heredity, Vol. 40, 1978, pp. 67-70. http://dx.doi.org/10.1038/hdy.1978.8

[18] P. S Baenziger, B. Moreno-Sevilla, C. J. Peterson, J. W. Schmidt, D. R. Shelton, D. D. Baltensperger, L. A. Nelson, D. V. McVey, J. E. Watkins and J. H. Hatchett, "Registration of 'Alliance' Wheat,” Crop Science, Vol. 35, 1995, p. 938.

http://dx.doi.org/10.2135/cropsci1995.0011183X0035000 $\underline{30056 x}$

[19] R. A. Graybosch, C. J. Peterson, P. S. Baenziger, L. A. Nelson, B. B. Beecher, D. D. Baltensperger and J. M. Krall, "Registration of 'Arrowsmith' Hard White Winter Wheat,” Crop Science, Vol. 45, 2005, pp. 1662-1663. http://dx.doi.org/10.2135/cropsci2004.0559

[20] J. W. Schmidt, V. A. Johnson, P. J. Mattern, A. F. Dreier, D. V. McVey and H. W. Somsen, "Registration of Buckskin Wheat,” Crop Science, Vol. 16, 1976, p. 743. http://dx.doi.org/10.2135/cropsci1976.0011183X0016000 $\underline{50054 x}$

[21] P. S Baenziger, B. Beecher, R. A. Graybosch, D. D. Baltensperger, L. A. Nelson, J. M. Krall, D. V. McVey, J. E. Watkins, J. H. Hatchett and M-S. Chen, "Registration of ‘Goodstreak' Wheat,” Crop Science, Vol. 44, 2004, pp. 1473-1474.

http://dx.doi.org/10.2135/cropsci2004.1473

[22] P. S Baenziger, B. Beecher, R. A. Graybosch, D. D. Baltensperger, L. A. Nelson, D. V. McVey, J. E. Watkins, J. H. Hatchett and M.-S. Chen, "Registration of 'Harry' Wheat,” Crop Science, Vol. 44, 2004, pp. 1474-1475. http://dx.doi.org/10.2135/cropsci2004.1474

[23] P. S Baenziger, B. Beecher, R. A. Graybosch, D. D. Baltensperger, L. A. Nelson, J. M. Krall, Y. Jin, J. E. Watkins, D. J. Lyon, A. R. Martin, Ming-Shun Chen and G. Bai, "Registration of 'Infinity CL' Wheat," Crop Science, Vol. 46, 2006, pp. 975-977. http://dx.doi.org/10.2135/cropsci2005.05-0044

[24] P. S Baenziger, B. Moreno-Sevilla, C. J. Peterson, D. R. Shelton, R. W. Elmore, P T. Nordquist, R. N. Klein, D. D. Baltensperger, L. A. Nelson, D. V. McVey, J. E. Watkins, J. H. Hatchett and G. Hein, " Registration of "Millennium' Wheat,” Crop Science, Vol. 41, 2001, pp. 13671369. http://dx.doi.org/10.2135/cropsci2001.4141367x

[25] J. W. Schmidt, V. A. Johnson, A. F. Dreier and P. J. Mattern, "Registration of Scout 66 Wheat," Crop Science, Vol. 11, 1971, p. 138.

[26] P. S Baenziger, B. Moreno-Sevilla, R. A. Graybosch, J. M. Krall, M. J. Shipman, R. W. Elmore, R. N. Klein, D. D. Baltensperger, L. A. Nelson, D. V. McVey, J. E. Watkins and J. H. Hatchett, "Registration of 'Wahoo' Wheat," Crop Science, Vol. 48, 2002, pp. 1752-1753. http://dx.doi.org/10.2135/cropsci2002.1752

[27] C. J. Peterson, D. R. Shelton, P. S. Baenziger, D. D. Baltensperger, R. A. Graybosch, W. D. Worrall, L. A. Nelson,
D. V. McVey, J. E. Watkins and J. Krall, "Registration of 'Wesley' Wheat," Crop Science, Vol. 41, 2001, pp. 260261. http://dx.doi.org/10.2135/cropsci2001.411260-ax

[28] M. Guedira, G. Brown-Guedira, D, Van Sanford, C. Sneller, E. Souza and D. Marshall, "Distribution of Rht Genes in Modern and Historic Winter Wheat Cultivars from the Eastern and Central USA,” Crop Science, Vol. 50, 2010, pp. 1811-1822. http://dx.doi.org/10.2135/cropsci2009.10.0626

[29] R. E. Allan, O. A. Vogel and J. C. Craddock Jr., “Comparative Response to Gibberellic Acid of Dwarf, Semidwarf, and Standard Short and Tall Winter Wheat Varieties," Agronomy Journal, Vol. 51, 1959, pp. 737-740. http://dx.doi.org/10.2134/agronj1959.0002196200510012 $\underline{0013 x}$

[30] M. J. Pinthus and M. Abraham, "Effects of Light, Temperature, Gibberellin $\left(\mathrm{GA}_{3}\right)$ and Their Interaction on Coleoptile and Leaf Elongation of Tall, Semi-Dwarf and Dwarf Wheat," Plant Growth Regulations, Vol. 18, 1996, pp. 239-247. http://dx.doi.org/10.1007/BF00024388

[31] M. J. Pereira, P. L. Pfahler, R. D. Barnett, A. R. Blount, D. S. Wofford and R. C. Littell, "Coleoptile Length of Dwarf Wheat Isolines: Gibberellic Acid, Temperature, and Cultivar Interactions,” Crop Science, Vol. 42, 2002, pp. 14831487. http://dx.doi.org/10.2135/cropsci2002.1483

[32] M. J. Pinthus, M. D. Gale, N. E. J. Appleford and J. R. Lenton, "Effect of Temperature on Gibberellin (GA) Responsiveness and on Endogenous $\mathrm{GA}_{1}$ Content of Ttall and Dwarf Wheat Genotypes," Plant Physiology, Vol. 90, 1989, pp. 854-859. http://dx.doi.org/10.1104/pp.90.3.854

[33] J. P. Nitsch and C. Nitsch, "Studies on the Growth of Coleoptile and First Internode Sections. A New, Sensitive, Straight-Growth Test for Auxins,” Plant Physiology, Vol. 31, 1956, pp. 94-111. http://dx.doi.org/10.1104/pp.31.2.94

[34] T. Yang, P. J. Davies and J. B. Reid, "Genetic Dissection of the Relative Roles of Auxin and Gibberellin in the Regulation of Stem Elongation in Intact Light-Grown Peas," Plant Physiology, Vol. 110, 1996, pp. 1029-1034.

[35] S. S. Snapp, S. M. Swinton, R. Labarta, D. Mutch, J. R. Black, R. Leep, J. Nyiraneza and K. O’Neil, “Evaluating Cover Crops for Benefits, Costs and Performance within Cropping System Niches,” Agronomy Journal, Vol. 97, 2005, pp. 322-332.

[36] E. A. Oelke, E. S. Oplinger, H. Bahri, B. R. Durgan, D. H. Putnam, J. D. Doll and K. A. Kelling, “Rye,” Alternative Crops Manual, Univiversity of Minnesota and Wisconsin, 1990. www.hort.purdue.edu

[37] R. G. Robinson, “Registration of Rymin Rye,” Crop Science, Vol. 13, 1973, p. 775. http://dx.doi.org/10.2135/cropsci1973.0011183X0013000 $60075 x$

[38] D. W. S. Mok and M. C. Mok, "Cytokinins: Chemistry, Activity and Function,” CRC Press, Boca Raton, 1994. 